\title{
Factors Affecting Students' Financial Literation: A Study on Widyatama University, Indonesia
}

\author{
Neneng Susanti*, Rima Rahmayanti, Rizal Ramdan Padmakusumah, R. Susanto
}

Widyatama University, Indonesia

Copyright $\mathrm{C} 2019$ by authors, all rights reserved. Authors agree that this article remains permanently open access under the terms of the Creative Commons Attribution License 4.0 International License

\begin{abstract}
This study aims to examine the factors that affect financial literacy with variables such as gender, pocket money, lifestyle, parental income, and financial learning. The research model used are descriptive and verification analysis. The population of this study was Widyatama University students and a sample of 122 people was obtained from whom they got questionnaire. Data analysis was used multiple linear regressions. The results showed that gender, pocket money, lifestyle, parent income, and financial learning had a significant effect on students' financial literacy. While for testing the hypothesis of partial pocket money, lifestyle, and financial learning have a significant effect on financial literacy. However, gender and parents' income do not have a significant effect on students' financial literacy.
\end{abstract}

Keywords Gender, Pocket Money, Lifestyle, Parents' Income, Financial Learning, Financial Literacy

\section{Introduction}

Financial literacy is closely related to financial management that the higher level of one's financial literacy, the better financial management of a person. Personal financial management is one application of the financial concept management on the individual level. Financial management, which includes planning, management and financial control activities are very important to achieve financial prosperity. Planning activities include activities to plan the allocation of income that obtained to be used for anything. Management is an activity of managing finances efficiently while control is an activity to evaluate whether financial management is in accordance with planned or budgeted.

The crisis of existence becomes concerning now, especially among the teenagers, encourage them to do various ways to get recognition in their environment. So it is caused that financial intelligence must be owned by millennial circles at this time. Financial intelligence is intelligence in managing personal assets (Widayati, 2012). In the globalization era and the proliferation of technological developments make difficult for individuals to manage personal assets to become something useful. Financial literacy is related to the individual welfare. Skills and knowledge in managing personal assets effectively are very important for each individual to support his or her well-being and it is not wrong in making financial decisions. Bhushan and Medury (2013) explain that financial literacy is very important for several reasons. Individual whose financial literacy is able to go through difficult financial times because of possible ownership of savings, insurance and investment diversification.

Financial literacy also directly correlates with positive financial behavior such as timely bill payments, loan installments, and savings before spending and using credit cards wisely. This can be of particular concern to adolescents, which is emphasized in students.

College is the first time for most students to manage finances independently without full supervision from parents. Students are in a very complex time because during their studies at the University, they must learn to be financially independent and responsible for the decisions that they make. Students are in a transition period from financial independence and during the college period students that they must also make plans, which will affect their welfare and success in the future.

Students as the next generation are expected to be able to have high financial literacy. Good financial literacy will shape students' financial intelligence. With high financial intelligence, students are able to manage finances well through an all-hedonic lifestyle. Financial intelligence in a long-term period will result students whose financial behavior wisely in carrying out proper and correct consumption and not easily affected by product offerings, which tend to place the position of the younger generation as a marketing segmentation. That way, students will develop into a generation that is able to control finances properly and correctly, which in general will have the mental effect to create the next generation that is anti-corruption. 
If the student is not equipped with knowledge and expertise in the field of finance, then the possibility of mistakes in the management of financial resources will be greater and welfare is difficult to achieve. Therefore, students need to be taught the right way of financial management so that the students can use their money maximally (Chen and Volpe: 1996 in Susanti 2013). The existence of financial knowledge and financial literacy will help adolescents in managing of personal financial planning, so that they can maximize the time value of money and the benefits will be obtained greater and will improve the standard of living (Margaretha, 2015).

Based on the questionnaire that the researcher obtained, the phenomenon that occurred at Widyatama University Bandung showed that students had a low level of financial behavior. The researcher conducted a survey to see the phenomenon of student financial behavior. The survey results for 122 respondents can be presented as follows:

Table 1. The Result of Widyatama University Students' Financial Survey

\begin{tabular}{|c|c|c|c|c|}
\hline No & Financial Behavior & Always & Sometimes & Never \\
\hline 1 & Write financial budget & 33 & 37 & 52 \\
\hline 2 & $\begin{array}{c}\text { Write expenses and } \\
\text { expenditures (daily, } \\
\text { monthly, etc.) }\end{array}$ & 29 & 34 & 79 \\
\hline 3 & $\begin{array}{c}\text { Providing funds for } \\
\text { unexpected expenses }\end{array}$ & 18 & 44 & 60 \\
\hline 4 & Save periodically & 22 & 40 & 60 \\
\hline 5 & Investation & 15 & 21 & 86 \\
\hline 6 & Minimize desire & 32 & 27 & 63 \\
\hline
\end{tabular}

Source: Primary Data Processed, 2019

Based on data in table 1 shows that student financial behavior tends to be low. This is a phenomenon, which shows the financial behavior of poor students

Based on this background, the research concentrates on factors that influence financial literacy and student financial behavior. The research was focused on gender, pocket money, lifestyle, parental income, and financial learning at universities for student financial literacy and student financial behavior that the object of research was students in one of the universities in Bandung.

Bandung city is one of the student cities where there are many universities from the other universities in Bandung. The author chose Widyatama University as the object of research, Widyatama University with its jargon "Friendly Campus for Future Business Pro" located on Jalan Cikutra Number 204A Bandung City is a campus adjacent to many restaurants, hangouts and tourist attractions which are very close to visit, plus the many shopping centers in Bandung such as "Paris Van Java", "Cihampelas Walk", "23 Paskal" and others. This condition does not rule out the possibility of students behaving consumptively.

Recognizing the importance of financial literacy among students, the authors are interested in conducting research with the title "Factors Affecting Student Financial Literacy"

\section{Literature Study}

\section{Financial Literacy}

Financial literacy is a basic need that someone needs so that they can avoid financial problems. The emergence of financial problems is not only because of the low level of income, but also can come from a lack of knowledge of someone in managing their finances. Financial Literacy shows the ability of individuals to utilize their resources to achieve and improve welfare (Dwiastanti \& Hidayat, 2016).

According to Vitt (in Widayati, 2012) Personal financial literacy is the ability to read, analyze, manage and communicate about personal financial conditions that affect material well-being. This includes the ability to distinguish financial choices, discuss money and financial issues without (or even though) inconvenience, plan for the future and respond competently to life events that affect financial decisions on a daily basis, including fact in the general economy.

\section{Gender}

Gender is identified as one of the factors that influence student financial behavior. Some studies reveal that men are better at managing finances than women (Ansong and Gyensare, 2012, Taylor and Wegland, 2009) in Laily (2014). This indicates that men have more confidence in making financial decisions compared to women who are more likely to be risk aversed compared to men. Furthermore, Wagland and Taylor (2009) added that the low self-esteem of women was also caused by their role as housewives as well as career women, making it very difficult to save. Women tended to be less able to control financial problems compared to men. This indicates that men and women have different motivations in financial matters.

\section{Money Pocket}

Pocket money is money brought for necessity at any time; pocket money (Departemen Pendidikan Nasional, 2008: 1513). Uang Jajan is money provided to be spent at any time (usually for children who do not have income and not too large amounts (Departemen Pendidikan Nasional, 2008: 1512)). Pocket money is a form of developing responsibility, so it needs to be accompanied by the planting of value for money in children, so that the money is given by parents and they use it for transportation or child savings. Pocket money can be used for food and other expenses that are of their need. While uangjajan is money given to children to buy food and beverage snacks while 
outside the home. The purpose of giving pocket money is as a medium for children's learning so that they can manage their finances properly.

\section{Life Style}

According to Setiadi (in Hariyono: 2015) lifestyle is classified as how people spend their time activities, interests that they consider important in their environment, and what they think about themselves and the environment. In the opinion of Engel et al (in Hariyono: 2015) lifestyle is a pattern of life, use and time that a person has. According to Suryani (2013: 57) lifestyle shows how a person allocates his opinion, and chooses products and services and various other choices when someone chooses alternatives in a group of products. According to Suyanto (2013: 141) lifestyle is related to efforts to make oneself exist in a certain way and different from other groups. It can be concluded that lifestyle is a way to spend the time of person's when she or he chooses alternatives in a group of existing types of products.

\section{Parent's Income}

Parents are biological mothers and biological fathers, elderly people, people who are considered old (clever, clever) (Poerwodarminta, 2002) in Maulani S (2016). According to Nababan and Sadalia (2012), parent income is the level of income obtained by the respondent's parents for a month either from receiving salary, wages, or receipts from the results of the business. Nidar and Bestari (2012) and Keown (2011) explain there is a relationship between the income of parents with financial knowledge (financial literacy). Margaretha and Pambudhi (2015) explain that parents with higher household incomes tend to have a higher level of financial literacy because they use financial instruments and services more often. Lusardi et al. (2010) stated that parental education, parental wealth and family financial experience effect children's financial literacy.

\section{Financial Learning in Collage}

According to Law No.20 of 2003 concerning National Education System Article 1 paragraph 20 learning is the process of interaction between students and educators and learning resources in a learning environment. According to Jihad and Haris (2013: 11) learning is a process that consists of a combination of two aspects, namely: learning is focused on what must be done by students, teaching is oriented on what must be done by the teacher as the instructor. In other words, learning is essentially a process of communication between students and educators as well as between students in order to change attitudes.

Learning is a system, which consists of various components that are interconnected with one another. The components include objectives, material, methods and evaluation. The four components of learning must be considered by the teacher in choosing and determining the media, methods, strategies and approaches to be used in learning activities

Learning in universities takes important rule in the process of forming student financial literacy. Effective and efficient learning will help students to have the ability of understanding, assessing and acting in their financial interests. So that students are able to implement learning outcomes in Collage with daily life.

Based on the explanation above, it can be concluded that financial learning in Collage can be obtained based on the objectives of financial management courses and company budgets, which can be used as an indicator that students get financial learning in Collage

\section{Branch Thinking}

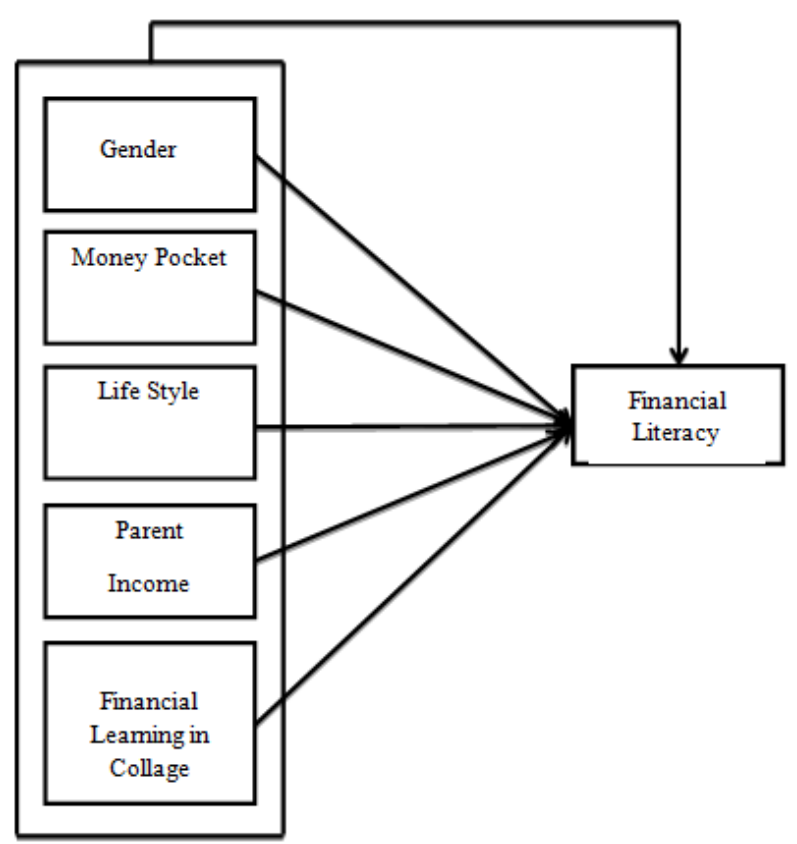

Based on the framework of the thinking developed, the hypothesis formulated in this study is as follows:

$H_{1}$ : Gender, Lifestyle, Pocket Money, Parents' Income, and Financial Learning in Higher Education together have a significant effect on financial literacy

$\mathrm{H}_{2} \quad$ : Gender has a significant effect on financial literacy

$H_{3} \quad$ : Pocket money has a significant effect on financial literacy

$$
\mathrm{H}_{4} \quad \text { : Lifestyle has a significant effect on financial }
$$
literacy

$H_{5} \quad$ :Parents' income has a significant effect on financial literacy

$H_{6} \quad$ : Financial Learning in Collage has a significant effect on financial literacy 


\section{Metodology}

\section{Research Variable}

1. Financial Literacy $(\mathrm{Y})$

Financial literacy in this study is individual knowledge about finance and the ability of individuals to make effective financial decisions.

\section{Gender (X1)}

Gender in this study consisted of men and women.

\section{Pocket Money (X2)}

The allowance in this study is how much students get pocket money for their living expenses during their education.

\section{Lifestyle (X3)}

The lifestyle in this study is a daily lifestyle that is run by a student during his education with technology and trends that are growing rapidly.

\section{Parents' Income (X4)}

Parents' income in this study is the monthly income earned by student parents.

\section{Financial Learning in Collage (X5)}

Financial learning in higher education in this study can be seen from several courses taught to accounting students such as financial management courses and company budgets.

\section{Analyisis Data Method}

The testing model used to test the hypothesis in this study uses multiple regression analysis. The multiple regression models aim to predict the relationship between the dependent variable and the independent variable. The regression equation is as follows:

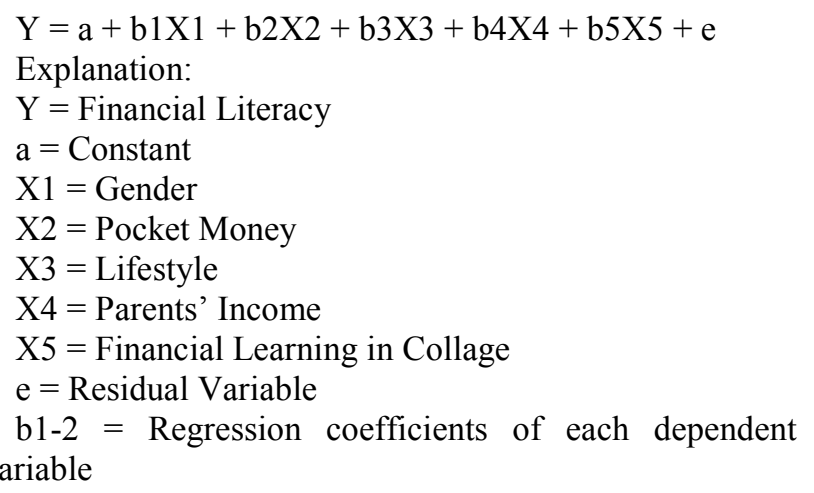

\section{Hypothesis Test}

In the classic assumption test, analysis of regression results or hypothesis testing can be done Hypothesis tests used

\section{a. Test Test (t-test)}

According to Ghozali (2016: 171), the t-test was conducted to determine the effect of each independent variable on the dependent variable.

\section{b. Simultaneous Significant Test (Statistic F Test)}

According to Ghozali (2016: 171). F-Test is conducted to find out whether the independent variables simultaneously or simultaneously affect the dependent variable.

\section{c. Determination Coefficient Test (R2)}

According to Ghozali (2016: 171) Multiple coefficient of determination (R2) or R squared is used to test the goodness-fit of the regression model, in other words $\mathrm{R}$ squared shows the magnitude of the influence of independent variables on the dependent variable. This coefficient of determination ranges from 0 to 1 or in percentages from 0 to $100 \%$.

\section{Research Result}

\section{Multiple Regression Analysis}

Table 2. Gender Regression Multiple Variable Results (X1) Pocket Money (X2) Lifestyle (X3) Parent Income (X4) Financial Learning in Collage (X5) for Financial Literacy (Y)

\begin{tabular}{|c|c|c|c|c|c|c|}
\hline \multicolumn{7}{|c|}{ Coefficients $^{a}$} \\
\hline & \multirow{2}{*}{ Model } & \multicolumn{2}{|c|}{ Unstandardized Coefficients } & \multirow{2}{*}{$\begin{array}{c}\text { Standardized Coefficients } \\
\text { Beta }\end{array}$} & \multirow{2}{*}{$\mathrm{T}$} & \multirow{2}{*}{ Sig. } \\
\hline & & B & Std. Error & & & \\
\hline \multirow{6}{*}{1} & (Constant) & 2,482 & ,266 & & 9,331 &, 000 \\
\hline & Gender &,- 006 &, 062 &,- 006 &,- 089 & ,929 \\
\hline & Pocket Money &, 460 &, 073 & ,626 & 6,290 &, 000 \\
\hline & Lifestyle &, 288 &, 126 & ,339 & 2,291 &, 024 \\
\hline & Parents' Income &,- 124 &, 123 &,- 137 & $-1,011$ &, 314 \\
\hline & Financial Learning &,- 287 & 083 &,- 305 & $-3,469$ &, 001 \\
\hline
\end{tabular}

Source: SPSS 24 and primer data processed 
Based on the table above, it can take the equation that the regression is:

$Y=2,729+0,031+2,474 \mathrm{E}-8+0,638-7,990 \mathrm{E}$

$-9-0,385$

From the multiple regressions, equation above it can be concluded that:

1. Constant value of 2,729; meaning that if Gender (X1) Pocket Money (X2) Lifestyle (X3) Parent's Income (X4) and Financial Learning in Collage (X5) are ignored (0), then Financial Literacy (Y) value is 2.729 units.

2. Gender regression coefficient (X1) 0.031 ; meaning that if the Gender variable increases by one unit and the other variable is constant, then the Financial Literacy variable $(\mathrm{Y})$ will increase by 0.031 units.

3. Regression Coefficient (X2) 2,474E-8; meaning that if the variable pocket money increases by one unit and the other variables are constant, then the Financial Literacy variable $(\mathrm{Y})$ will increase by $2,474 \mathrm{E}-8$ units.

4. Lifestyle regression coefficient (X3) 0,638 ; meaning that if the Lifestyle Style variable increases by one unit and the other variables are constant, then the Financial Literacy variable (Y) will increase by 0.638 units.

5. Regression Coefficient of Parent Income (X4) -7.990E-9; meaning that if the Parent Income variable increases by one unit and the other variable are constant, then the Financial Literacy variable $(\mathrm{Y})$ will decrease by $-7.990 \mathrm{E}-9$ units.

6. Regression coefficient of Financial Learning in collage (X5) - $-0,385$; meaning that if the variable of Financial Learning in Collage increases by one unit and the other variable is constant, then the Financial Literacy variable $(\mathrm{Y})$ will decrease by $-0,385$ units.

\section{Hypothesis Test}

In the classic assumption test, analysis of regression results or hypothesis testing can be done. Hypothesis tests used:

\section{Test F (Simultaneous Test)}

According to Ghozali (2016: 171). F-Test is conducted to find out whether the independent variables simultaneously or simultaneously affect the dependent variable. From the results of data processing, using the $\mathrm{F}$ Test or ANOVA Test can be seen in the table as follows:
Table 3. Joint Testing of All Independent Variables

\begin{tabular}{|c|c|c|c|c|c|c|}
\hline \multicolumn{7}{|c|}{$\operatorname{ANOVA}^{a}$} \\
\hline \multicolumn{2}{|r|}{ Model } & Sum of Squares & df & $\begin{array}{c}\text { Mean } \\
\text { Square }\end{array}$ & $\mathrm{F}$ & Sig. \\
\hline \multirow{3}{*}{1} & Regression & 12,587 & 5 & 2,517 & 24,082 &, $000^{\mathrm{b}}$ \\
\hline & Residual & 12,126 & 116 &, 105 & & \\
\hline & Total & 24,713 & 121 & & & \\
\hline \multicolumn{7}{|c|}{ a. Dependent Variable: Financial Literacy } \\
\hline \multicolumn{7}{|c|}{$\begin{array}{l}\text { b. Predictors: (Constant), Financial Learning, Gender, Pocket Money, } \\
\text { Parents' income, Lifestyle }\end{array}$} \\
\hline
\end{tabular}

Source: SPSS 24 and primer data processed

Based on table 3 sig. that is 0,000 with $\alpha=0,05$, then $\mathrm{H} 0$ is rejected $(0,000<0,05)$, it can be concluded that Gender (X1) Pocket Money (X2) Lifestyle (X3) Parent Income (X4) Financial Learning in Collage (X5) jointly influences Financial Literacy $(\mathrm{Y})$.

\section{T-Test (Partial Test)}

According to Ghozali (2016: 171), the t-test is conducted to determine the effect of each independent variable on the dependent variable; partial hypothesis testing is intended to test the significant effect of independent variables den partially bound.

Table 4. Result T-Test

\begin{tabular}{|c|c|c|c|}
\hline \multicolumn{2}{|c|}{ Model } & $\mathrm{t}$ & Sig. \\
\hline \multirow{3}{*}{} & (Constant) & 9,331 &, 000 \\
\cline { 2 - 4 } & Gender &,- 089 &, 929 \\
\cline { 2 - 4 } & Pocket Monet & 6,290 &, 000 \\
\cline { 2 - 4 } & Lifestyle & 2,291 &, 024 \\
\cline { 2 - 4 } & Parents' Income & $-1,011$ &, 314 \\
\cline { 2 - 4 } & Financial Learning & $-3,469$ &, 001 \\
\hline
\end{tabular}

Source: SPSS 24 and primer data processed

Based on table 4, it can be concluded as follows:

1. In testing the hypothesis that the Gender variable produces sig. equal to 0.929 greater than the expected significance level $(0.929>0.05)$, then Gender partially does not have a significant effect on Financial Literacy.

2. In testing the hypothesis that the variable pocket money produces sig. equal to 0,000 smaller than the expected significance level $(0,000<0,05)$, then partially pocket money has a significant effect on financial literacy. 
3. In testing the hypothesis that for Lifestyle variables produce sig. for 0.024 smaller than the expected significance level $(0.024<0.05)$, partially Lifestyle has a significant effect on Financial Literacy.

4. In testing the hypothesis that for income variables parents produce sig. equal to 0.314 greater than the expected significance level $(0.314>0.05)$, then partially Parental Income does not significantly influence Financial Literacy.

5. In testing the hypothesis that the Financial Learning variable produces sig. equal to 0.001 smaller than the expected significance level $(0.001<0.05)$, then partially Financial Learning has a significant effect on Financial Literacy.

Determination Coefficient Test (R2)

According to Ghozali (2016: 171) Multiple coefficient of determination (R2) or R squared is used to test the goodness-fit of the regression model, in other words $\mathrm{R}$ squared shows the magnitude of the influence of independent variables on the dependent variable. The measurement results of the coefficient of determination can be seen in the table as follows:

Table 5. Results of the Gender Variable Determination Coefficient (X1) Pocket Money (X2) Lifestyle (X3) Parent Income (X4) Financial Learning in Collage (X5) for Financial Literacy (Y) Model Summaryb

\begin{tabular}{|c|c|c|c|c|c|}
\hline Model & $\mathrm{R}$ & $\mathrm{R}$ Square & $\begin{array}{c}\text { Adjusted R } \\
\text { Square }\end{array}$ & $\begin{array}{c}\text { Std. Error of } \\
\text { the Estimate }\end{array}$ & $\begin{array}{c}\text { Durbin-Wats } \\
\text { on }\end{array}$ \\
\hline 1 &, $714^{\mathrm{a}}$ &, 509 &, 488 &, 32332 & 1,722 \\
\hline
\end{tabular}

a. Predictors: (Constant), Financial Learning, Gender, Pocket Money, Parents' Income, Lifestyle

b. Dependent Variable: Financial Literacy

The coefficient of determination (R-squared) of 0.509 or $50.9 \%$ shows that Gender (X1) Lifestyle (X2) Pocket Money (X3) Parent Income (X4) Financial Learning in Collage (X5) has an effect of 50, 9\% of Financial Literacy (Y). While the remaining $48.8 \%$ is influenced by other variables that they are not examined in this study.

\section{Discussion}

\section{Gender Influence on Financial Literacy}

The Gender variable in this study has a value that accepts $H_{0}$ so that Gender has no significant effect on Financial Literacy.

This study supports research is conducted by Margaretha and Sari (2015) and Nidar and Bestari (2012) which revealed that gender does not significantly influence financial literacy.

Chung and Park (2014) state that the higher the level of education a person takes, the higher the chance for financial literacy. Respondents in this study had a fairly high education so that both men and women tended to use logic. In line with Widayati (2012) who revealed that the existence of good knowledge about finance from an early age can help students have a prosperous life in the future. This is supported by Lusardi and Michell (2010) who revealed that education from parents has a large role from financial literacy. Learning from an early age helps a person have the ability to understand, assess, and act in their financial interests.

Unlike the research conducted by Margaretha and Pambudhi (2015) and Krishna, et al. (2010) which shows that gender influences student financial literacy.

\section{The Effect of Pocket Money on Financial Literacy}

The Pocket Money variable in this study has a value that receives $H_{1}$ so that the Pocket Money has a significant effect on Financial Literacy.

This research is supported by Nidar and Bestari (2012) stating that pocket money has a significant effect on financial literacy.

The influence of whether or not a large monthly allowance for students on financial literacy is more influenced by student control in controlling their finances. Boarding students should be able to manage their competitiveness not to live wastefully and spend their money wisely. This is because the level of income of their parents is different; the pocket money they get is used to buy food and drinks. The receipt of their allowances makes them more wasteful in buying goods.

In contrast to the research conducted by Megasari (2014); Çocuk \& Yanpar (2018); Hossain, 2018; Anwar, 2018 which states that pocket money does not have a significant effect on financial literacy.

\section{Effects of Lifestyle on Financial Literacy}

The Lifestyle variable in this study has a value that accepts $H_{1}$ so that Lifestyle has a significant effect on Financial Literacy.

Lifestyle continues to develop, because many students have a lot of pocket money because both parents work, this is in accordance with the opinion of Lamb et al (2001: 81) lifestyle continues to evolve because consumers can choose from a number of products and services that continue to grow , and most have money to make more choices. The increase in purchasing power is caused by the increase of double income families. Family and peers also contribute to the formation of student lifestyles. According to Suryani (2013: 129) the family is the closest environment because consumers carry out more intensive interactions. Peer friends have a role that is the tendency of adolescents to get acceptance and recognition of their peers, encouraging them to be easily influenced by their groups.

\section{Effects of Parent Income on Financial Literacy}

The Parent Income variable in this study has a value that accepts $H_{1}$ so that Gender has no significant effect on Financial Literacy. 
This can be caused because the level of income of parents will affect their financial attitudes. Parents who have high income tend to have more financial planning. This makes someone more skilled and good at managing their finances. Keown (2011); Keskin \& Korkutata (2018) explains that there is a relationship between the income of parents with financial knowledge. Older people with higher household incomes tend to have a higher level of financial literacy because they use financial services more often. The high income level of parents will make students have more opportunities to develop their financial management skills. Low parent income will result in a small amount of pocket money being given so that students must be able to manage their finances wisely.

In contrast to the research conducted by Nidar and Bestari (2012) which states that parents' income has a positive effect on the level of student financial literacy.

\section{Impact of Financial Learning in Collage on Financial Literacy}

Financial Learning Variables in Higher Education in this study have a value that accepts $H_{1}$ so that Financial Learning in Collage has a significant effect on Financial Literacy.

This research is supported by Haryono (2008), which states that the quality of learning processes in schools (one of place to find an education) has a positive effect on economic rationality and economic morality of students. Likewise, research conducted by Gutter (2008) states that financial education has a significant positive effect on financial attitudes. Huddleston et al. in Gutter (2008); Aina (2017) also states that personal finance programs have a positive impact on the level of financial literacy and the level of self-efficacy.

In this study, the influence of learning in collage on financial literacy on attitude aspects was lower than the effect of learning in Collage on cognitive financial literacy. This can be interpreted that the process of learning financial management is considered quite good, and the introductory learning process of accounting is considered good, so it can be understood if getting financial management learning, and introducing accounting, can improve student financial literacy.

\section{Conclusions}

Based on the discussion of the previous chapters, conclusions can be drawn as follows:

1. From the results that have been investigated by the researchers show that Gender (X1) Pocket Money (X2) Lifestyle (X3) Parent Income (X4) Financial Learning in Collage (X5) jointly influences Financial Literacy (Y)
2. From the results that have been investigated by the researcher show that Pocket Money (X2) Lifestyle (X3) and Financial Learning in Collage (X5) have a significant effect on Financial Literacy (Y). Whereas, Gender (X1) and Parent Income (X4) do not have a significant influence on Financial Literacy $(\mathrm{Y})$.

\section{REFERENCES}

[1] Aina, J. K. (2017). The Effect of Peer Instruction (PI) on the Pre-Service Teachers' Learning of Current Electricity. International Journal of Education, Training and Learning, $1(1), 1-8$.

[2] Anwar, M. N. (2018). Acquisition of Skills for Listening Comprehension: Barriers and Solutions. International Journal of English Language and Literature Studies, 7(3), $50-54$.

[3] Çocuk, H. E., \& Yanpar Yelken, T. (2018). The Effect of the Web-Based Digital Story Applications on the Digital Literacy Levels of Turkish Teacher Candidates. Asian Journal of Education and Training, 4(2), 132-136.

[4] Dikria Okkydan Mintarti Sri 2016. Pengaruh Literasi Keuangandan Pengendalian Diri Terhadap Perilaku Konsumtif Mahasiswa Jurusan Ekonomi Pembangunan Fakultas Ekonomi Universitas Negeri Malang 2013.Jurnal Pendidikan Ekonomi, Vol. 09, No. 2

[5] Fadillah. 2017. Pengaruh Penghasilan Orang Tua dan Uang Saku Terhadap Prestasi Mahasiswa (STEBIS IGM). Jurnal Keuangan dan Bisnis

[6] Herawati, Candiasa, Yadnyanyadan Suharsono 2018. Pengaruh Kualitas Pembelajaran Keuangandan Literasi Keuangan Terhadap Financial Self Efficacy Mahasiswa Akuntansi. Jurnal Pendidikan Ekonomi, Manajemendan Keuangan Vol.2 No.2.

[7] Hossain, M. M. (2018). Implementing Social Justice in Teaching and Learning English at University Level in Bangladesh: Necessities, Approaches and Challenges. International Journal of English Language and Literature Studies, 7(1), 7-14.

[8] Keown, L. A. (2011). The financial knowledge of Canadians. Canadian Social Trends, 91, (11-008-X, 30-39.

[9] Keskin, Ö., \& Korkutata, A. (2018). Reviewing Academic Motivation Levels of Students Study in Different Faculties in Terms of Certain Variables (Sakarya University Case). Journal of Education and e-Learning Research, 5(2), 208-216.

[10] Kusumaningtyas, Indarti dan Drs.Norida Canda Sakti M.Si. 2017. Pengaruh Literasi Keuangan dan Gaya Hidup Terhadap Perilaku Konsumtif Siswa Kelas XI IPS DI SMA NEGERI 1 TAMAN SIDOARJO. Jurnal Pendidikan EKonomi. Volume 5 Number 3

[11] Laily,Nujmatul. 2014. Pengaruh Literasi Keuangan Terhadap Perilaku Mahasiswa Dalam Mengelola Keuangan. Universitas Negeri Malang 
[12] Margaretha, F. Dan Pambudhi, R. A. (2015) "Tingkat Literasi Keuangan Pada Mahasiswa S-1,” 17(1), Hal. 7685.Doi: 10.9744/Jmk.17.1.76.

[13] Margaretha, Farah dan Reza Arief Pambudhi.2015.Tingkat Literasi Keuangan Pada Mahasiswa S-1 Fakultas Ekonomi. JMK, VOL. 17, NO 1, MARET 2015 76-85

[14] Melmusi, Zerni. 2017. Faktor-Faktor Yang Mempengaruhi Literasi Finansial Mahasiswa Fakultas Ekonomi. Majalah Ilmiah, Vol 24 No 2.

[15] Mendari, Anastasia Sri dan Suramaya Suci Kewal. 2013. Tingkat Literasi Keuangan Di Kalangan Mahasiswa STIE MUSI.

[16] Nidar, S. R. Dan Bestari, S. (2012) "Personal Financial Literacy among University Students (Case Study At Padjadjaran University Students, Bandung, Indonesia)," 2(4), Hal. 162-171.

[17] Rachmasari, Adetya. 2018. Faktor-Faktor Yang Mempengaruhi Literasi Keuangan Mahasiswa. Skripsi. Universitas Islam Indonesia. 